Canadian University Music Review

Canadian University Music Review

Revue de musique des universités canadiennes

\title{
Same As It Ever Was? Musicology Continues to Wrestle with Rock
}

\section{Susan Fast}

Volume 21, numéro 1, 2000

Music Studies in the New Millennium : Perspectives from Canada Les études en musique dans le nouveau millénaire : perspectives canadiennes

URI : https://id.erudit.org/iderudit/1014477ar

DOI : https://doi.org/10.7202/1014477ar

Aller au sommaire du numéro

\section{Éditeur(s)}

Canadian University Music Society / Société de musique des universités canadiennes

\section{ISSN}

0710-0353 (imprimé)

2291-2436 (numérique)

Découvrir la revue

Citer cet article

Fast, S. (2000). Same As It Ever Was? Musicology Continues to Wrestle with Rock. Canadian University Music Review / Revue de musique des universités canadiennes, 21(1), 40-53. https://doi.org/10.7202/1014477ar
Résumé de l'article

Popular music studies is approached from a number of disciplinary perspectives. Most recently, musicologists and music theorists have become interested in the analysis of popular music. This has sparked heated debates both within musicology and music theory, and outside it from sociologists and other cultural critics. The author traces some of that debate and argues for a popular music analysis that takes social meanings into account, using language that does not alienate those who are not professional musicians. It is argued that this is of paramount importance, since popular music is one of the most important means through which many people in the West shape their worlds.
All Rights Reserved (C Canadian University Music Society / Société de musique des universités canadiennes, 2000
Ce document est protégé par la loi sur le droit d'auteur. L'utilisation des services d'Érudit (y compris la reproduction) est assujettie à sa politique d'utilisation que vous pouvez consulter en ligne.

https://apropos.erudit.org/fr/usagers/politique-dutilisation/ 


\title{
SAME AS IT EVER WAS? MUSICOLOGY CONTINUES TO WRESTLE WITH ROCK
}

\author{
Susan Fast
}

In short, the study of popular music should also include the study of popular music. ${ }^{1}$

Last year (1999), a collection of essays entitled Reading Rock and Roll appeared from Columbia University Press. In the introduction, the editors, both of whom teach in departments of English, state that the essays in this collection take a "textually oriented approach," that is, they deal with specific artists and specific works, which the editors rightly claim is a relatively new idea given the tendency of popular music studies to have been "dominated by the sociological bent of the Birmingham School of cultural studies," with its general suspicion of close readings. "[W]e believe," the editors argue, "that poststructuralist and postmodern theories of textuality enable readings that pay close attention to the minutest details of individual compositions while still situating these texts within their social, historical, political, and cultural contexts."2 This is an admirable objective to be sure. What makes the editors' statement remarkable-to me, a musicologist, at least-is that none of the thirteen essays in the collection addresses the sound of the music in anything but a superficial way, neither do the authors draw on recent musicological work on popular music that does address sound and that does situate that sound socially, historically, politically, and culturally: one thinks here of the groundbreaking studies by Robert Walser, John Shepherd, David Brackett, Steve Waksman, Sheila Whiteley, Richard Middleton, Paul Théberge, Timothy Taylor, Adam Krims, and Susan McClary, to name a few. ${ }^{3}$ After a decade that witnessed the

1 Susan McClary, "Same As It Ever Was: Youth Culture and Music," Microphone Fiends: Youth Music, Youth Culture, ed. Andrew Ross and Tricia Rose (New York and London: Routledge, 1994), 38.

2 Keven J. H. Dettmar and William Richey, eds., Reading Rock and Roll: Authenticity, Appropriation, Aesthetics (New York: Columbia University Press, 1999), 2.

3Robert Walser, Running with the Devil: Power, Gender and Madness in Heavy Metal Music (Hanover, N.H.: University Press of New England, 1993), and "Rhythm, Rhyme, and Rhetoric in the Music of Public Enemy," Ethnomusicology 39 (1994): 193-217; idem, with Susan McClary, "Start Making Sense: Musicology Wrestles with Rock," in On Record: Rock, Pop and the Written Word, ed. Simon Frith and Andrew Goodwin (New York: Pantheon Books, 1990), 277-92; John Shepherd, Music as Social Text (Cambridge: Polity Press, 1991); David Brackett, Interpreting Popular Music (Cambridge: Cambridge University Press, 1995); Steve Waksman, Instruments of Desire: The Electric Guitar and the Shaping of Musical Experience (Cambridge, Mass.: Harvard University Press, 1999); Sheila Whiteley, Women and Popular Music: Sexuality, Identity and Subjectivity (New York: Routledge, 2000); Richard Middleton, Studying Popular Music (Milton Keynes: Open University Press, 1990); Paul Théberge, Any Sound You Can Imagine: Making Music/Consuming Technology (Hanover and London: 
historic movement of musicology and music theory towards popular music (ponderous and filled with resistance though that movement has been and continues to be), it is distressing that such a collection of essays could still appear. It is not the only study recently published that virtually ignores the sounds of popular music, and I want to stress that many of the essays are interesting and make a valuable contribution to popular music scholarship; I single it out because the editors seem to think that they are, indeed, dealing with all the parameters of "popular music," without examining "popular music" at all-a criticism that was levelled at scholars of popular music some six years ago by McClary, to say nothing of Shepherd's Music as Social Text, or Middleton's Studying Popular Music, which appeared earlier in the 1990s and which argue not only for the importance of taking musical sounds into account, but which offer analytical paradigms for how such work might be undertaken.

With musicologists and theorists finally turning their attention to popular music, the place of musical analysis in popular music studies has become quite contentious, with criticism coming both from those who think it matters and those who do not. On the one hand, there are those trained outside musicology and music theory who continue to ignore the sound, often without comment, as the Reading Rock and Roll authors have done, or those who argue against the importance of analysis largely, as Adam Krims puts it, because of the widespread notion that "analysing popular music in the 'musicological' sense distances one from the real engagements of both artists and audiences, both of whom presumably do not relate to any significant extent to the music as modelled." 4 Despite his latest book, Performing Rites, I think Simon Frith still falls into the latter camp, for while he has finally addressed sound in this book, and has tried to work his way through some arguments about how sound might produce meaning, he seems in the end to argue that these meanings are only relevant to the musicologist or theorist and that the interpretations made by them are important only for producers and not consumers of music. He seems also to suggest that the interpretations being made by musicologists are to be taken by them as the only possible way to hear the music, an idea that I am quite certain is anathema to all the scholars I have mentioned above. ${ }^{5}$

Analysis matters to me and the musicologists I have named because we believe that important cultural work is being undertaken through the sounds of popular music, not exclusively through lyrics, dress, attitude, artist biographies, or the subcultural activity that might emerge around a style of music.

\footnotetext{
Wesleyan University Press, 1997); Timothy Taylor, Global Pop: World Music, World Markets (New York and London: Routledge, 1997); Adam Krims, Rap Music and the Poetics of Identity (Cambridge: Cambridge University Press, 2000); Susan McClary, Feminine Endings: Music, Gender, Sexuality (Minnesota: University of Minnesota Press, 1991); idem, Conventional Wisdom: The Content of Musical Form (Berkeley: University of California Press, 2000). I would include my own work here, among which is the essay, "Music, Context and Meaning in U2," in Expression in Pop-Rock Music, ed. Walter Everett (New York: Garland, 2000), 33-57, and In the Houses of the Holy: Led Zeppelin and the Power of Rock Music (New York: Oxford University Press, 2001).

4Krims, Rap Music, 18-19.

5 Simon Frith, Performing Rites: On the Value of Popular Music (Cambridge, Mass.: Harvard University Press, 1996).
} 
Musical sounds, in fact, work in tandem with these other attributes as a very important site of social meaning; it is in the musical sounds that "the politics of music often reside," as Susan McClary has written, "especially as [popular music] intersects with the body and destabilizes accepted norms of subjectivity, gender and sexuality." 6 That is why, she continues, "we need to find ways of understanding the socially grounded rhetorical devices by means of which [popular] music creates its intersubjective effects; otherwise, the medium remains privatized and mystified, impervious to cultural criticism." 7 Despite what Frith says, these are not only the concerns of musicologists, although we happen to be the ones best equipped-right now, at least-to address these issues. In fact, these are issues that should, and do, concern anyone who makes or consumes popular music; the reason that many popular music scholars do not address the sounds, indeed the reason they are suspicious of analyses that do, is because we have for the last two centuries mystified musical practices, not only by disconnecting them from social concerns, but by developing sophisticated analytical techniques that are the purview of an exclusive group of highly-trained professionals.

Even among those who are engaged in the analysis of popular music, though, there is deep division about how it should be carried out and to what ends. Despite a decade of "The New Musicology," music is still frequently thought of and discussed by musicologists and theorists as residing in a realm outside the social. As a consequence, there exists considerable resistance to analyses that place it there. In this formalist paradigm, analysis exists in order to reveal the structure of a piece of music and is usually accomplished using technical language that leaves non-specialists in the dark, further mystifying the music and negating its immense power as a means by which people structure their worlds. ${ }^{8}$ It is mostly those trained as music theorists who are engaged in strictly formalist analysis of popular music, and one of their arguments is that there needs to be "foundational" studies of popular music, using traditional analysis, as there is for classical music, otherwise there will be no groundwork on which to base any other kind of analysis. ${ }^{9}$ Given the erroneous statements that are

6McClary, "Same As It Ever Was," 32.

7 Ibid.

8For examples of this kind of research in popular music, see Walter Everett, The Beatles as Musicians (New York: Oxford University Press, 1999); John Covach and Graeme Boone, eds., Understanding Rock (New York: Oxford University Press, 1998), or many of the essays in Expression in Pop-Rock Music. Allan Moore's book, Rock: The Primary Text (Milton Keynes: Open University Press, 1993), falls mostly on the formalist side, although Moore does try to link some aspects of the music to the culture out of which it came.

9John Covach makes this argument in "Popular Music, Unpopular Musicology," in Rethinking Music, ed. Nicholas Cook and Mark Everist (New York: Oxford University Press, 1999), 469: "Recent work by Lawrence Kramer and Susan McClary, for example, interprets Western art-music from a socio-cultural perspective; but Kramer's hermeneutic readings of Beethoven, Wagner and Liszt, and McClary's feminist interpretations of Monteverdi, Bach and Brahms depend to a significant extent on the reader's knowledge of how the canon or art-music is organized ... By contrast, the history-or histories - of popular music and its myriad styles has, for the most part, not yet been established in anything but the most preliminary sense. There is still plenty of 'traditional musicology' left to do in popular music; in fact this work has hardly begun." 
frequently made by journalists and academics about popular music styles, there is certainly something to be said for studies that would get the musical facts for particular artists straight. ${ }^{10}$ And because there are almost no studies of popular music that deal with specific style characteristics of an artist, a genre, or a "school," a scholar who wants to study popular music always has to begin at the very beginning, mapping out stylistic characteristics, contextualizing these within a given artist's repertory, a genre, a time period, etc. But while the argument that formalist analysis alone will provide such a foundation is a tempting proposition, the premise behind it is faulty. It will only get us so far, and only with certain repertories, repertories that have already come to be privileged by most music theorists working on popular music: the Beatles, progressive rock, jazz-rock fusion, or earlier studies on Tin Pan Alley, for example, while music that does not conform to the analytical models is left aside (funk, rap, electronica, among other genres); or, perhaps worse, music that fits the model badly is poured into it anyway, either showing up its "deficiencies" in the process, or placing emphasis on an element of the music (usually pitch) that is relatively inconsequential for the song's impact." Such disciplining of popular music is problematical and unnecessary; analytical paradigms are best left fluid, shaped to account for particular songs, artists, and repertories.

Further, formalist analysis leaves out the crucial factor of culture, which many theorists seem eager to do. John Covach has been an outspoken proponent of scholarship from musicologists and theorists that deals with "the music itself," which he sets in opposition to "popular music [as] inherently social." "I propose ... that popular music can also be considered as inherently musical, and only secondarily as social," and "writing as one who has spent many years playing and listening to popular music ... I have always been concerned with the way the music sounds, the way particular songs are situated within a single style and across various styles, and not so much with the kind of social or political statement that the music may have been making." 12 Another advocate for traditional musical analysis of popular music has been Walt Everett, who opens his essay, "Confessions from Blueberry Hell," by charging that his interest in analyzing pitch structures in popular music has been unfairly criticized both by "reviewers and other pop/rock scholar peers ... for betraying the heretic spirit of rock and roll by approaching it with ears trained by the academy," and by those who believe that "by focussing on elements of music that are seldom appreciated by the rock-performer and rock audience masses ... I am ignoring what is important to most of those listeners-the social value inherent in the music's reception."13

10 I point to several erroneous claims that have been made about the musical style of Led Zeppelin, for example, in In the Houses of the Holy.

11 See Richard Middleton's critique of musicology and its relationship to popular music studies in Studying Popular Music, Chapter 4.

12Covach, "Popular Music, Unpopular Musicology," 466.

13Everett, "Confessions from Blueberry Hell," Expression in Pop-Rock Music, 269. 
While I have learned much by reading the work of both these scholars, I take issue with their arguments about the way in which musical analysis of popular music should be undertaken, and also why it should be undertaken in the first place. Given the way in which I began this essay, I certainly understand Covach's frustration with research that takes into account only "social" aspects of popular music without any recourse to the sounds, and the distinction he makes between this and studies that address the sound, but I cannot follow him in his suggestion that there is something called "the music itself" that can be separated out from "the social." As Robert Walser has recently written, "we only have the problem of connecting music and society if we've separated them in the first place." 14 Covach's very desire to make this distinction is socially and historically situated, stemming from the nineteenth- and twentieth-century view of music as religious experience that must not be contaminated by association with the social, and in particular the body. Everett makes his view on this quite clear, when he says:

I believe that purely musical effects [are] nearly always connected in some way to matters of pitch relationships ... If the masses believe they are attracted only to rhythm or loud volume and "can't hear" the pitch or have no conscious understanding of functional tonal relations, I say they are merely unaware of why, for instance, they become more excited by expanded dominant-seventh retransitions enhanced by added uncontrolled dissonance than they do in the face of less tonally valiant alternations of weak III and VI chords. ${ }^{15}$

Everett further states that "pitch relationships often have strong expressive implications for what are often thought to be extra-pitch subjects." 16 In other words, Everett's aim is to perpetuate the mind/body split that has so dominated studies of classical music (to say nothing of Western culture in general), reducing the importance of rhythm and other parameters of popular music to the subservience of pitch-the element for which theoretical paradigms are most well-developed, and therefore the element that can most easily be objectified in academic studies. For these reasons, it is also the element that is most likely to legitimate popular music studies in the eyes of skeptics within musicology and music theory (although as I mentioned above, it alienates those outside our profession): if we can talk about "expanded dominant-seventh retransitions enhanced by uncontrolled dissonance" in pop music, then it must be worthy of academic study! It is not that such retransitions are unimportant: the difficulty lies in the ideologically loaded way in which Everett describes his aims. Like most music theorists, he wants to reduce music to matters of pitch, to take the body out of the process more or less altogether, and to educate "the masses" into his way of thinking about music. While there is a place for pitch-centred analysis and a pedagogical role for the analyst in popular music

14Robert Walser, review of Understanding Rock: Essays in Musical Analysis (Oxford University Press, 1997) in MLA Notes (forthcoming). My thanks to Robert Walser for providing me with a copy of his review prior to its publication.

15Everett, "Confessions from Blueberry Hell," Expression in Rock-Pop Music, 270.

16Ibid., 271-72. 
studies, we need to approach these ideas with a good deal of caution and sensitivity to the multiple and ever-changing ways in which people experience the music they love.

The problem is that pitch in and of itself, as McClary and Walser have pointed out, is of ten not the most interesting or important parameter in popular music:

The musical interest resides elsewhere [than in pitch], in the dimensions of music that musicology systematically overlooks ... [D] eveloping methods for getting at those overlooked dimensions requires not only noticing them, but also constructing a vocabulary and theoretical models with which to refer to them and to differentiate among them. How does one talk about microtonal inflections when one has decided that therein lies a clue to Muddy Waters' genius? How does one account on paper for the strut ... one's body picks up and responds to immediately and without conscious thought of Prince's " $U$ Got the Look?" How does one deal with what Roland Barthes calls "the grain of the voice" in Janis Joplin's singing? It is no wonder that musicologists have preferred sticking to pitch and metre (both of which are measurable and can be charted with some degree of certainty), for these other parameters resistor have not so far been subjected to-intellectual control. ${ }^{17}$

But both Covach and Everett continue to argue that "traditional" forms of musical analysis, meaning those that are related primarily to issues of pitch, are suitable for use in the analysis of popular music, even in the face of much scholarship, like McClary's and Walser's, Shepherd's, and Middleton's, that has worked painstakingly to argue against this; Covach's response to some of this scholarship, in fact, has been to suggest that a socially grounded musical analysis of popular music is, at the present time, demanding too much: "[these scholars] not only ask musicologists to look at different music [than that of the classical music canon] but also tell them to care about different issues in all the music they study ... this kind of radical change is therefore unlikely to occur." 18

But, in fact, it already has occurred, and as Robert Walser points out in his review of Understanding Rock (a collection of essays edited by Covach and Graeme Boone, to which Walt Everett as well as a number of other music theorists have contributed), the kind of traditional analytical work being undertaken by these scholars is "a disappointing retreat from the state of the art in musicological study of popular music into an intellectually isolated formalism." Walser also points out how they have

worked the new terrain with their old tools-something that anthropologists and comparative musicologists learned not to do nearly a century ago. Judging from the essays themselves, these authors hope to confirm the transhistorical and transcultural utility of certain methods of analysis by colonizing new repertoires with them, and they seek to prove the worthiness of rock music by

17McClary and Walser, "Start Making Sense," 282.

18Covach, "Popular Music, Unpopular Musicology," 469. 
locating within at least some of it a number of already prestigious traits, such as organic unity, formal complexity, and resemblances to European classical music. The main purpose of this volume thus appears to be the reciprocal legitimation of rock music and modernist analytical techniques. ${ }^{19}$

What those of us doing socially grounded musical analysis would argue is that one does, indeed, have to do it "all" simultaneously, that is, both analysis that takes into account how the sounds work from a technical point of view, and how these sounds are socially meaningful. Figuring out "how the song goes," (and getting this right!) is a critical first, not a last step in coming to understand it. As Richard Middleton put it a decade ago, "[r]ather than pulling to one side, with the traditional musicologists, or the other, with the 'total critics' of musicology, it will be better to look both ways, living out the tension." 20 Further, we cannot simply, or only, apply traditional means of music analysis, which was developed to account for only certain features of a narrowly defined repertory of classical music. And if traditional analysis is appropriate to use in a given circumstance, then the least technical language available should be used in order that the largest number of people possible will understand the argument; for what this endeavour should be about is not analysis for the sake of it, but analysis that attempts to account for the powerful ways in which musical sounds affect people's lives.

Studies that model how such work might be undertaken are what we might call the real "foundation" for a new kind of popular music studies that takes sound into account. These are still relatively few in number, but they are already taking on a certain shape. Building on Middleton's work, David Brackett has argued that

the notion of the "musical code" offers a way of theorizing the connections between musical sound and such "extra-musical" factors as media image, biographical details, mood, and historical and social associations; it can explicate the connection between an individual piece and the conventions of the period that surround it, the connection between a particular piece and the general langue from which it derives, and permit us to speculate about the connection between the musical sounds we hear and the "human universe" implied by the lyrics. ${ }^{21}$

Robert Walser theorizes a similar approach, preferring to think of popular music in terms of "discourse" instead of "code," while also pointing to the fluid nature of such discourses:

The analytical notion of discourse enables us to pursue an integrated investigation of musical and social aspects of popular music. By approaching musical genres as discourses, it is possible to specify not only certain formal characteristics of genres but also a range of understandings shared among

19Walser, review of Understanding Rock.

20Middleton, Studying Popular Music, 123.

21 Brackett, Interpreting Popular Music, 9. 
musicians and fans concerning the interpretations of those characteristics ... Like genres and discourses, musical meanings are contingent but never arbitrary. There is never any essential correspondence between particular musical signs or processes and specific social meanings, yet such signs and processes would never circulate if they did not produce such meanings. Musical meanings are always grounded socially and historically, and they operate on an ideological field of conflicting interests, institutions, and memories. $^{22}$

Space allows for only one specific example of such analysis, and I have chosen one that I know particularly well and have built on in my own work. In Running with the Devil, Walser realizes such socially grounded analysis on several levels, moving from the interpretation of general musical characteristics to analyses of specific works. In Chapter 2, for example, he begins by linking such stylistically critical technical elements as distortion, sustain, and volume in heavy metal guitar playing and singing to notions of power, making this point by situating the notion of distortion as a positive sound characteristic historically (" $t$ t]o the horror of [audio engineers] in the 1960's they began to receive requests from guitar players to produce devices that would deliberately add electronic distortion ... it is only at a particular historical moment that distortion begins to be perceived in terms of power rather than failure, intentional transgression rather than accidental overload, as music rather than noise"23). While Walser makes a convincing argument for the connection between distortion and power himself ("distortion functions as a sign of extreme power and intense expression by overflowing its channels and materializing the exceptional effort that produces it"24), he also turns to those working in the recording industry for their interpretations: "[a]s one successful heavy metal producer puts it, 'Distortion gives that feeling of ultimate power. The more distortion you get, the more satisfying it is. There's something slightly superhuman, psychologically speaking, about the sustain, the nearly endless notes." 25

In a separate but related article, Walser theorizes the link between distortion and power further using philosopher Mark Johnson's concept of image schemata. Briefly, Johnson argues that our worlds are shaped by the understanding we have of our bodies, that "abstract" concepts are, in fact, based in the physical, not the mental-in fact, that the two cannot be separated at all. ${ }^{26}$ Johnson argues that it is through the notion of metaphor that image schemata (basic physical structures of experience such as force, balance, or cycle) are linked to language. Walser uses one of Johnson's image schemata, that of "force" to help explain why we might recognize distortion in heavy metal as a sign of power:

22Walser, Running with the Devil, 28-29.

23 Ibid., 42.

24 Ibid.

25 Ibid.

26Mark Johnson, The Body in the Mind: The Bodily Basis of Meaning, Imagination, and Reason (Chicago: University of Chicago Press, 1987). 
The concept of force arises out of many kinds of bodily experience. We have bodies that are acted upon by many kinds of force: gravity, wind, and the impingement of external objects and other living beings, as well as the forces we experience internally, as the body maintains its dynamic equilibrium: pulse, respiration, burping ... Soon we learn that we can be sources of force ourselves: we learn to manipulate our environment and our bodies, to grab things, to pull ourselves through space. We eventually formulate a concept of "force," and learn to articulate it through language, but it is grounded in our preconceptual physical experiences ... What experiences of distortion do we have that might connect it metaphorically with the image schemata of force? ${ }^{27}$

Walser then goes on to connect the concept of overdriven amplifiers or human voices, which produce distortion, to the concept of force, in the way that I have outlined above.

Later, in Chapter 2 of his book, Walser turns to a more detailed analysis of the song "Running with the Devil" by Van Halen, focussing on the musical strategies employed to "enact" a central tenet of the lyrics, individual (bourgeois) freedom, which "is presented as a lack of social ties: no love, no law, no responsibility, no delayed gratification." 28 Walser points to David Lee Roth's solitary voice in the verses, which relates "an individual experience; the singer is reflective and confessional as he relates his experience." This is contrasted with the chorus, in which the addition of backing vocals suggests group solidarity and acts to support the singer and affirm his fantasy or freedom, about which Roth clearly has some doubts (indicated even in the chorus, where he interjects tortured screams and wails). Walser points to another musical characteristic that further supports this reading and that is the use of mode, a crucial signifier in heavy metal. In "Running with the Devil," the mode moves from a dark Aeolian progression to Mixolydian: "every two bars we are lifted out of the familiar negative Aeolian terrain into the perfect resolution of the major mode's tonic ... This modal shift is the song's 'hook,' and the formal/narrative structure of the song is built around it. After each statement of a verse, there is a tremendous affective charge in moving into this chorus material." 29 The modal shift is accompanied by a change in the other elements of the music as well: power chords are added in the chorus, filling out the sparse texture of the verses, and these as well as the backing vocals create a louder dynamic level. In addition, Walser theorizes the brief guitar solo in this song within the context of the narrative. Guitar solos, he rightly argues, are a crucial feature of hard rock and metal songs; they are "characterized by fast licks and soaring, amazing virtuosity that can create a sense of perfect freedom and omnipotence; they model escape from social constraints, extravagant individuality." 30 In other words, the guitar solo is one of the most powerful moments of transcendence in a hard rock or metal song. But "Running

27Walser, "The Body in the Music: Epistemology and Musical Semiotics," in College Music Symposium 31 (1991): 117-126; here 120.

28 Walser, Running with the Devil, 52.

29Ibid., 52-53.

30 Ibid., 53. 
with the Devil" includes only an abbreviated solo-four bars long-and one that is technically quite simple. Walser argues that this short and simple guitar solo underscores the twin concerns of this song, and of the genre of metal: control and freedom. Further, he argues that because the constant modal shift already signifies "transcendence," there is less necessity for an extended guitar solo to fulfill this function.

In this kind of analysis, attention is paid both to the conventions of the genre as well as to the details of a particular piece. Walser has, indeed, "looked both ways" here, figuring out how the music is put together at a level that takes into account a lot of detail (much of which I have omitted in my brief sketch here), contextualizing those details within an historically situated genre of music, and then taking the difficult but essential leap into interpretation. Many of his observations are grounded in comments made by the musicians, others in the recording industry (many of these comments come from interviews given to the popular press), or fans, whom he interviewed for his project. He is also quick to point out that his interpretations are not intended to be definitive; in fact, at the end of his analysis of "Running with the Devil," he states, "I have specified meanings that I identified as discursively produced, as though all metal fans had the same understanding of all metal songs. In fact my interviews with heavy metal fans and musicians tell that this is not the case." 31 In later chapters of the book, Walser gets more specifically at how this genre of music is meaningful to different people-to women, for example, and members of the gay community, as well as white males who have been viewed in other studies, somewhat erroneously, as the most important demographic group for metal. An interpretive window has been opened into the socially situated ways in which this music is structured, but the interpreter is willing to consider other explications. In fact, another socially grounded interpretation of distortion in metal singing has been offered by John Shepherd, who has argued that the strain heard in these almost exclusively white, male rock voices may signify the inability among this demographic to express emotion; instead of hearing, as Walser does, an overflow of emotion in such singing, Shepherd hears it as the struggle to bring forth repressed emotion..$^{32}$ What is important here is less whether one or the other of these authors has got it "right," than to revel in the fact that such interpretations force us to reflect on what we are hearing and how the sounds might be meaningful. Both ways of hearing distorted rock vocals are probably "right" depending upon who is listening and who is producing the music, factors that must always be taken into account in making analyses.

Walser's study and those like it by Brackett, Waksman, and others, model a kind of musical analysis that will be of central importance to the future of popular music studies, and perhaps also the future of music education and the place of music within Western culture. First and foremost, it begins to demystify musical sound by linking the various ways in which it is structured in specific genres and/or songs to the social. Some traditional analytical tech-

32Shepherd, "Music and Male Hegemony," in Music as Social Text, 152-73. 
niques that are pitch-centred are used, but these are combined with new approaches that aim to deal with other elements of the music. Walser's discussion of timbre (distortion) in metal relies in part on his understanding of the technology used to create it, and this is an area that will require much more investigation. Musicologists need to be working with record producers and engineers to understand how technology is used to create certain effects, since the sound (i.e., timbre, production values, etc.) of many recordings is critically important both to the musicians and to those who listen to the music; we also need to know more about how the instruments used in popular music work (especially the electric guitar), and how various sounds are produced on them. Paul Théberge's book, Any Sound You Can Imagine: Making Music/Consuming Technology, goes a long way in tracing the history of and explaining the technology used in music making, as well as linking the use of various technologies to social issues. There needs to be much more energy put into developing alternative methods of analysis as well. David Brackett uses spectrum photos which "capture all the sounding physical vibrations present in a recording. The presence or absence of higher partials sounding simultaneously with a fundamental largely determines our perceptions of a pitch's timbre or tone color ... The spatial orientation of the spectrum mirrors that of our hearing: lower sounds appear lower in the picture space higher sounds appear higher." 33 Brackett's use of spectrum photo analysis stems in part from his desire to move away from traditional notation, which is extremely problematical for popular music studies, since it not only tells us very little about the important elements of timbre and rhythm (the latter of which can almost never be transcribed accurately using conventional notation), but also tends to alienate those who cannot read music. ${ }^{34}$ In my own work, I have tried to keep the use of notated musical examples to a minimum, describing the events of a recorded or live performance in prose, with references to lyrics that help orient the reader to the moment of the song I am describing, but this is also far from an ideal methodology.

Walser's analysis of distortion in metal also relies on theory, in this case the theory of bodily based meaning by the philosopher Mark Johnson. Critical theory has already facilitated much new thought in musicology in the realms of both popular and classical musics. I think there are two particularly important areas of theory, so far little explored, that will prove fruitful to popular music analysts: work coming out of performance studies and, more specifically, work around the body and social meaning. Johnson's theory of image schemata will undoubtedly continue to prove fruitful in this area, ${ }^{35}$ but various works in the areas of kinesics and dance theory should also be examined, ${ }^{36}$

33Brackett, Interpreting Popular Music, 65.

34 Middleton and Brackett both discuss the advantages and pitfalls of conventional musical notation in popular music analysis.

35 I have used Johnson's image schemata to help analyse some of Led Zeppelin's riff-based music in In the Houses of the Holy, Chapter 4.

36I have found some of Ray Birdwhistle's book, Kinesics and Context: Essays on Body Motion Communication (Philadelphia: University of Pennsylvania Press, 1970), to be useful, as well as David McNeil, Hand and Mind: What Gestures Reveal about Thought (Chicago: University of Chicago Press, 
since so much popular music acts on the body in ways that have only begun to be investigated. Richard Middleton has made a beginning, linking, for example, various ways in which melody is structured in popular music to "kinetic patterns," one of these being "the 'shout-and-fall' type" (found in The Who's "My Generation," for example), which he says "suggests 'affective outpouring,' 'self-offering of the body, 'emptying and relaxation." 37 Work in performance studies-such as that by Richard Schekner, Victor Turner, and Eugenio Barba -has been helpful to me in terms of moving away from the piece of popular music as object, to a consideration of complete performances: how a song might be understood within the context of an entire album, for example, how it might be changed in performance, where it might be placed in the running order of a concert, etc. ${ }^{38}$ In addition, performance studies can help popular music analysts make sense of the correspondences between visual and aural aspects of performance (for example, the particular movements of a performer in relation to the sounds $s /$ he is creating, the relationship of particular sounds in a performance to the way an instrument is held, or the use of the space on the stage to any of the above).

In Running with the Devil, Walser also begins to take into account the voices of fans, musicians, and those in the recording industry in making his analyses. The voice of the analyst needs to be balanced with those of the musicians and fans, regardless of whether the analyst is writing purely for the academic community (which I think is a mistake in any case) or not. Analysis should not take the music away from those who produce and consume it. This is why ethnography should be an important component of the analysis of popular music: what aspects of the music are compelling to fans and how do they talk about these? Many fans are amateur musicians and so discussions of form, chord changes, phrasing, and especially timbre are often addressed by them (what kind of guitar is being used, with what kind of effects, for example), albeit usually not with the same technical vocabulary used by musicologists or theorists (this should hardly trouble us). Having been part of two fan communities (those for Led Zeppelin and U2), I know that non-musician fans also discuss the music: what works about a particular song and what does not, how does the voice sound, when do the drums come in, etc. How we do ethnography in popular music studies remains problematical. Walser's method was to hand out questionnaires at metal concerts he attended and then to conduct follow-up interviews with some fans who completed the questionnaire; I posted a copy of my Led Zeppelin fan questionnaire on the main Internet discussion list for the band and on a Web site, and I sent a hard copy to one of the fanzines with the highest circulation. But to get at specific questions about the music, one might take an approach similar to that of Daniel Cavicchi in his book Tramps

1992).

37 Middleton, Studying Popular Music, 207.

38Richard Schekner, Performance Theory (New York: Routledge, 1988); Victor Turner, From Ritual to Theatre: The Human Seriousness of Play (New York: Performing Arts Journal Publications, 1982); Eugenio Barba, The Paper Canoe: A Guide to Theatre Anthropology, trans. Richard Fowler (New York: Routledge, 1995). 
like Us: Music and Meaning among Springsteen Fans, ${ }^{39}$ in which he worked over a period of time with a small number of committed fans, having extended discussions with them as opposed to limiting himself to a brief questionnaire. My preoccupation with making the fans' and musicians' voices an integral part of analysis comes largely out of my own subject position as a fan of most of the music about which I have written: too often I have read academic or journalistic work on popular music written from the perspective of an outsider, who simply does not "get" the culture. This kind of writing is alienating to those who do get it. And this brings me back to the question of some of the analysis being undertaken by music theorists, as well as those scholars of popular music who do not address the sounds at all: what will be gained by a body of formalist or social analysis that does not resonate at all with the people who make and consume the music? The aim should be to create studies that work to draw musicians and fans into them, to be part of them, in order that we can all make sense of the powerful experiences that people have with popular music.

And here is what the payoff of such work could, ideally, be. Popular music is consumed so pervasively, especially in industrialized countries, that if we create a body of critical work that convincingly links the ways in which the sounds are structured with social issues, using a language that is comprehensible to the majority of people, there might be a chance that music will come to be seen as something worthy of study by everyone, not in order to "get cultured," but in order to develop awarenesses of: how it acts as a way in which to understand our bodies and our sexuality; how we forge relationships with people; and how we understand and create the world around us. That might be a very good reason to make the study of music centrally important in our educational system, something that might lead eventually to the possibility of increasingly subtle and technical interpretations of music being accessible to a large number of people who understand the value of knowing something about how musical sound works. But this is still in the future. As Timothy Taylor has put it: "Right now, musicology probably has more to learn from cultural studies than vice versa: that music is not just a thing, but something that people do, something that people listen to. But cultural studies, in the meantime, could learn from musicology's traditional work, which it does very well: that music as a thing is important too." 40

39Daniel Cavicchi, Tramps like Us: Music and Meaning among Springsteen Fans (New York: Oxford University Press, 1998). Cavicchi's study is a landmark work in popular music studies, but his concern was not so much in getting the fans he interviewed to discuss the technical aspects of the music.

40Timothy Taylor, review of Tricia Rose, Black Noise: Rap Music and Black Culture in Contemporary America (Hanover, N.H.: University Press of New England, 1994), Andrew Ross and Tricia Rose, eds., Microphone Fiends: Youth Music and Youth Culture (New York: Routledge, 1994), and Barry Shank, Dissonant Identities: The Rock ' $n$ ' Roll Scene in Austin, Texas (Hanover, N.H.: University Press of New England, 1994), in The Drama Review: The Journal of Performance Studies 41, no. 2 (1997): 169. 


\begin{abstract}
Popular music studies is approached from a number of disciplinary perspectives. Most recently, musicologists and music theorists have become interested in the analysis of popular music. This has sparked heated debates both within musicology and music theory, and outside it from sociologists and other cultural critics. The author traces some of that debate and argues for a popular music analysis that takes social meanings into account, using language that does not alienate those who are not professional musicians. It is argued that this is of paramount importance, since popular music is one of the most important means through which many people in the West shape their worlds.
\end{abstract}

